\title{
Urotensin II Stimulates Vascular Endothelial Growth Factor Secretion From Adventitial Fibroblasts in Synergy With Angiotensin II
}

\author{
Nana Song, PhD; Wenhui Ding, MD; Songyun Chu, PhD; Jing Zhao, PhD; \\ Xiao Dong, PhD; Beibing Di, MD; Chaoshu Tang, MD
}

\begin{abstract}
Background: The adventitia plays an important role in and is considered to be the initiating site for vascular remodeling. Urotensin II (UII) and angiotensin II (Ang II) are the two most important vascular peptides involved in vascular remodeling in the adventitia. Nevertheless, little is known about their effect on the expression of vascular endothelial growth factor (VEGF). It was hypothesized that both UII and Ang II could induce VEGF expression in adventitial fibroblasts and VEGF may play a role in cell proliferation and collagen I synthesis induced by UII or Ang II.

Methods and Results: Growth-arrested adventitial fibroblasts were incubated in serum-free medium with UII and/ or Ang II and inhibitors of the mitogen-activated protein kinase (MAPK) pathway or VEGF-neutralizing antibodies. The VEGF expression was evaluated using enzyme-linked immunosorbent assay (ELISA), while the proliferation and collagen I synthesis were detected using methyl thiazol tetrazolium (MTT) assay and ELISA. It was found that: (1) both UII and Ang II could stimulate VEGF expression in adventitial fibroblasts and they had a synergistic effect; (2) MAPK pathway inhibitors could inhibit VEGF secretion induced by UII and/or Ang II; and (3) VEGF-neutralizing antibodies could inhibit UII/Ang II-induced cell proliferation and collagen synthesis in adventitial fibroblasts.
\end{abstract}

Conclusions: Induction of VEGF expression may be a new mechanism involved in vascular remodeling for UII and Ang II. (Circ J 2012; 76: 1267-1273)

Key Words: Adventitial fibroblasts; Angiotensin II; Urotensin II; Vascular endothelial growth factor; Vascular remodeling

$\mathbf{V}$ ascular remodeling is an important field of cardiovascular physiology and has the highest potential for useful translation from basic research to clinical medicine. It is a keystone of many cardiovascular diseases including hypertension, atherosclerosis and restenosis. The adventitia plays a critical role in vascular remodeling. ${ }^{1}$ Following injury, adventitial fibroblasts are activated and differentiate into myofibroblasts, which have contractile properties and significant proliferative and synthetic activities, migrating to the intima and contributing to neointima formation., ${ }^{1,2}$ The differentiation, migration and proliferation adventitial fibroblasts and collagen synthesis in these cells are involved in vascular remodeling. ${ }^{3}$ However, the mechanisms behind vascular remodeling in the adventitia are still not completely understood.

Urotensin II (UII) and angiotensin II (Ang II) are two of the most important and most studied peptides involved in vascular remodeling. They have been recognized as potent vascular constrictors that, along with their receptors, are up-regulated in patients with hypertension, atherosclerosis and restenosis following balloon angioplasty. ${ }^{4-6}$ They can induce the proliferation of vascular endothelial cells and vascular smooth muscle cells..$^{7-9}$ Recent studies have shown that UII and Ang II may induce vascular remodeling in the adventitia by inducing the differentiation, migration and proliferation and collagen synthesis in adventitial fibroblasts.,10 The above effects are mainly achieved through the binding of UII and Ang II with their respective receptors to activate downstream pathways such as mitogen-activated protein kinase (MAPK), protein kinase $\mathrm{C}$ (PKC) and calcium channels. ${ }^{3}$ However, the exact mechanisms by which UII and Ang II mediate vascular remodeling in the adventitia are still largely unclear.

VEGF is one of the most important angiogenic cytokines involved in vascular remodeling. ${ }^{11-16}$ In vivo experiments have

Received August 9, 2011; revised manuscript received January 13, 2012; accepted January 16, 2012; released online March 2, 2012 Time for primary review: 16 days

Department of Cardiology, Peking University First Hospital, Beijing (N.S., W.D., S.C., J.Z., X.D., B.D.); Department of Physiology and Pathophysiology, Peking University, Beijing (C.T.), China

Name of grant: National Natural Science Foundation of China (No. 30871066).

Mailing address: Wenhui Ding, MD, Department of Cardiology, Peking University First Hospital, No. 1, XiShiKu Street, XiCheng District, 100034, Peoples Republic of China. E-mail: dwh_rd@126.com

ISSN-1346-9843 doi:10.1253/circj.CJ-11-0870

All rights are reserved to the Japanese Circulation Society. For permissions, please e-mail: cj@j-circ.or.jp 
shown that VEGF can induce intimal hyperplasia in rabbit carotid arteries. Researchers have also demonstrated that VEGF can stimulate the proliferation of vascular cells, including vascular endothelial cells and smooth muscle cells, and can induce the proliferation and migration of adventitial fibroblasts. ${ }^{10,17}$ Previous studies have shown that VEGF can be produced by vascular wall cells that express the VEGF receptor Flt-1, such as endothelial cells and vascular smooth muscle cells. ${ }^{10} \mathrm{Jin}$ et al found that Flt-1 was expressed in adventitial fibroblasts; however, little is known about whether adventitial fibroblasts serve as a novel source of VEGF. ${ }^{17}$

The effects of Ang II and UII on VEGF expression have been mostly studied in vascular endothelial cells and smooth muscle cells. Ang II has been reported to induce VEGF expression in human endothelial cells and smooth muscle cells. ${ }^{10}$ Furthermore, researchers have shown that VEGF is involved in Ang II-induced cell proliferation and collagen synthesis.9,18 However, Albertin et al found that UII did not affect VEGF expression in human endothelial cells. ${ }^{19}$ In adventitial fibroblasts, Ang II was shown to up-regulate the expression of Flt-1, a receptor of VEGF. However, the true effect of Ang II and UII on VEGF expression in adventitial fibroblasts is currently unknown. Furthermore, it is still unclear whether VEGF is involved in cell proliferation and collagen synthesis induced by Ang II and UII.

In the present study, we hypothesized that both Ang II and UII could induce VEGF expression in adventitial fibroblasts and that VEGF was involved in Ang II- and UII-induced cell proliferation and collagen synthesis.

\section{Methods}

\section{Animals}

Male Sprague-Dawley rats weighing 120-180g were supplied by the Animal Center, Peking University, Beijing, China. Experimental protocols were in compliance with the Animal Management Rules of China (Documentation 55, 2001, Ministry of Health, China).

\section{Reagents}

Rat UII and Ang II were purchased from Phoenix Pharmaceuticals Inc (Belmont, CA, USA). Fetal bovine serum (FBS) was from Hyclone (Logan, UT, USA). Dulbecco's modified Eagle's medium (DMEM), methyl thiazol tetrazolium (MTT) assay [3-(4,5-dimethylthiazol-2-yl)-2,5-diphenyltetrazolium bromide] and DMSO (dimethyl sulfoxide) were from Sigma (St. Louis, MO, USA). PD123319, PD98059 and SB203580 were bought from Promega (USA). Urantide and losartan were supplied by Peptides International, Inc (Louisville, KY, USA). Rat VEGF enzyme-linked immunosorbent assay (ELISA) kits and rat collagen Type I ELISA kits were from BIOPCE (Beijing, China). The VEGF antibody used for western blot was from Santa Cruz. The neutralizing antibody against VEGF and $\mathrm{IgG}$ was from R\&D Systems (Minneapolis, MN, USA).

\section{Adventitial Fibroblast Cell Culture}

Aortic adventitial fibroblasts were prepared according to the method used by Tsuruda et al, with some modifications. ${ }^{20}$ Briefly, rats were anesthetized with isoflurane and rapidly decapitated. The full length of the thoraco-abdominal aorta was isolated in a pool of $4^{\circ} \mathrm{C}$ phosphate-buffered saline (PBS) after gently opening the parietal pleura, separating loose connective tissue and collateral vessels and transecting the segmental arteries at their origins. Under magnification, the adventitial and medial layers could be distinguished at both ends of the aorta. Endothelial cells were removed by gently rubbing the lumen with the blunt side of dissecting scissors, and the medial layer was peeled off using two forceps. The remaining tissues, predominantly the adventitia, were cut rapidly into small pieces and placed in a $25 \mathrm{~cm}^{2}$ tissue culture flask with DMEM medium containing 20\% FBS. The explants were cultivated until large colonies of cells formed surrounding the explants. Fibroblasts grew from these explants in approximately 4-5 days. After achieving confluence, they were harvested with trypsin, used for experiments at passage 3-5 and cultured with DMEM containing $10 \%$ FBS. The morphology and growth characteristics of the cells were typical of fibroblasts and were distinguishable from smooth muscle cells by the absence of a "hill-and-valley" growth pattern and the lack of $\alpha$-smooth muscle actin staining.

\section{Study Design}

To examine the induction of VEGF expression through UII and Ang II in adventitial fibroblasts, cells were subcultured in 96-well plates and incubated with serum-free medium (containing $0.5 \% \mathrm{FBS}$ ) for $24 \mathrm{~h}$. After synchronization, the medium was changed to DMEM without any serum. Thereafter, the adventitial fibroblasts were incubated in the presence or absence of UII and/or Ang II. To explore the molecular mechanisms of these proteins, inhibitors such as urantide (an antagonist of the UII receptor [GPR14]), losartan (an antagonist of the Ang II type I receptor [AT 1 R]), PD123319 (an antagonist of the Ang II type II receptors $\left[\mathrm{AT}_{2} \mathrm{R}\right]$ ), and the MAPK inhibitors PD98059 and SB203580 were used.

Based on the experimental design, cells were divided into the following groups: (1) control group, cells were only incubated with serum-free DMEM; (2) UII group, $10^{-10}$ to $10^{-6} \mathrm{~mol} / \mathrm{L}$ of UII was added to the medium; (3) Ang II group, $10^{-10}$ to $10^{-6} \mathrm{~mol} / \mathrm{L}$ of Ang II was added to the medium; (4) time-dependent research group, $10^{-8} \mathrm{~mol} / \mathrm{L}$ of UII or $10^{-6} \mathrm{~mol} / \mathrm{L}$ of Ang II was added to the medium for $6 \mathrm{~h}$ to $72 \mathrm{~h}$; (5) UII and Ang II group, $10^{-10} \mathrm{~mol} / \mathrm{L}$ of UII and $10^{-10} \mathrm{~mol} / \mathrm{L}$ of Ang II or $10^{-8} \mathrm{~mol} / \mathrm{L}$ of UII and $10^{-7} \mathrm{~mol} / \mathrm{L}$ of Ang II were added, respectively; and (6) UII and/or Ang II and inhibitors group, cells were pre-treated in serum-free DMEM with urantide $\left(10^{-6} \mathrm{~mol} / \mathrm{L}\right)$, losartan $\left(10^{-6} \mathrm{~mol} / \mathrm{L}\right)$, PD123319 $\left(10^{-6} \mathrm{~mol} / \mathrm{L}\right)$, the MAPK inhibitor PD98059 $\left(10^{-6} \mathrm{~mol} / \mathrm{L}\right)$ or SB20358 $\left(10^{-6} \mathrm{~mol} / \mathrm{L}\right)$, VEGF-neutralizing antibody $(20 \mu \mathrm{g} / \mathrm{ml})$ or Ig G (which was used as negative control for VEGF-neutralizing antibody), and incubated with UII $\left(10^{-8} \mathrm{~mol} / \mathrm{L}\right)$ and/or Ang II $\left(10^{-6} \mathrm{~mol} / \mathrm{L}\right)$. Serum was collected from the cells after $24 \mathrm{~h}$ of incubation except for the time-dependent research group.

\section{Enzyme-Linked Immunosorbent Assay for VEGF and Collagen Type I}

The medium was collected from cultured adventitial fibroblasts with or without the treatments mentioned above and centrifuged immediately. The supernatant was measured using rat VEGF and Collagen Type I ELISA kits according to the manufacturer's instructions. The absorbance of colored products was determined using a microplate reader set to $450 \mathrm{~nm}$.

\section{Western Blot Assay for VEGF}

After incubation, the culture medium was removed, and adventitial fibroblasts were lysed directly in the dish at $4^{\circ} \mathrm{C}$ for $30 \mathrm{~min}$ with lysis buffer $(20 \mathrm{mmol} / \mathrm{L}$ Tris, $150 \mathrm{~mol} / \mathrm{L} \mathrm{NaC} 1$, $1 \mathrm{~mol} / \mathrm{L}$ ethylenediaminetetraacetic acid, $1 \%$ Nonidet P-40, $2 \mathrm{~mol} / \mathrm{L} \mathrm{Na3VO} 4)$ supplemented with $1 \mathrm{~mol} / \mathrm{L}$ phenylmethylsulphonyl fluoride, $5 \mathrm{mg} / \mathrm{ml}$ leupeptin. Lysates were cleared by centrifugation at $12,000 \mathrm{~g}$ for $15 \mathrm{~min}$ at $4^{\circ} \mathrm{C}$. Protein con- 
A

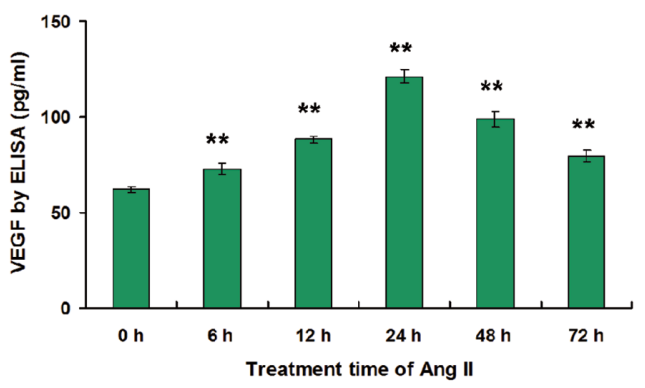

C

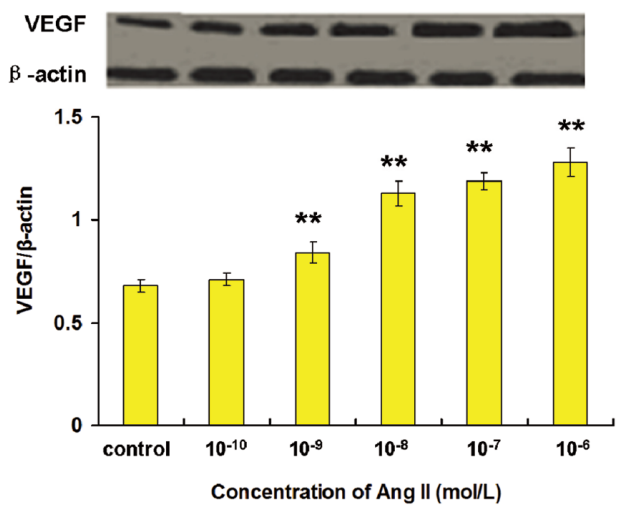

B

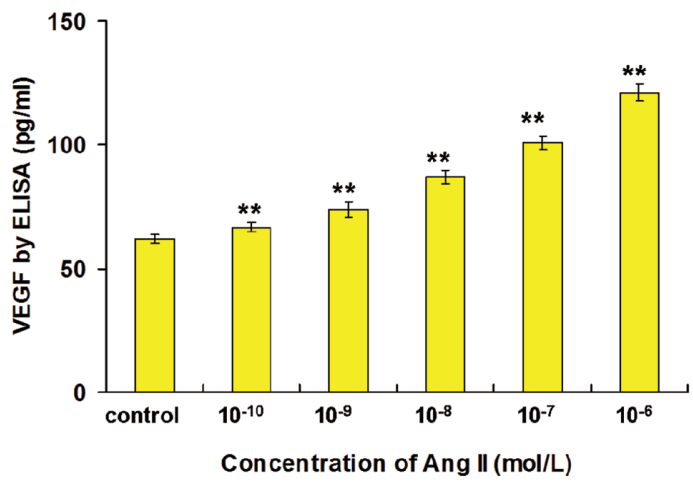

D

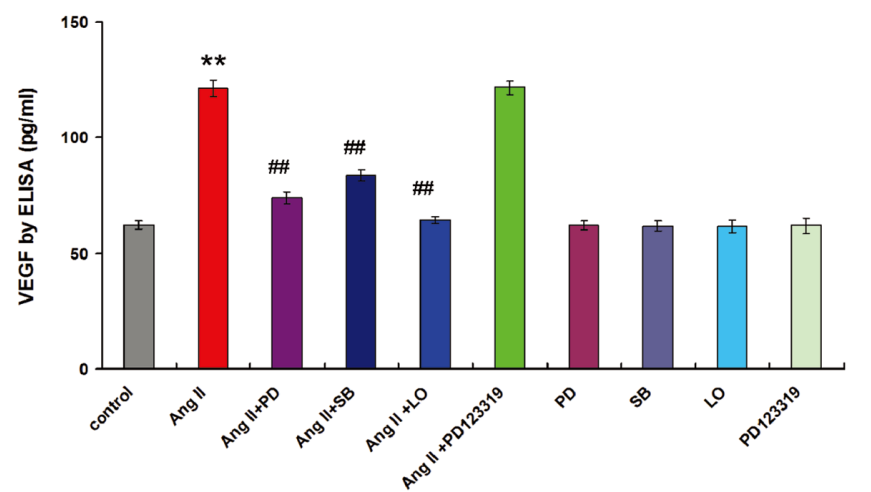

Figure 1. Angiotensin II stimulates VEGF expression in adventitial fibroblasts. (A) Time course of Ang II-mediated induction of VEGF secretion $(n=6)$. Rat adventitial fibroblasts were treated with Ang $\|\left(10^{-6} \mathrm{~mol} / \mathrm{L}\right)$ for the time indicated. (B) Effect of different concentrations of Ang II on VEGF secretion in cultured adventitial fibroblasts in vitro $(n=6)$. Cells were stimulated with different concentrations of Ang II (10-10 to $\left.10^{-6} \mathrm{~mol} / \mathrm{L}\right)$ for $24 \mathrm{~h}$. (C) Effect of different concentrations of Ang II on VEGF expression in cultured adventitial fibroblasts in vitro assayed by western blot $(n=6)$. (D) Effect of different inhibitors on VEGF secretion induced by Ang II $\left(10^{-6} \mathrm{~mol} / \mathrm{L}\right)(\mathrm{n}=6)$. PD, PD98059; SB, SB203580; LO, Losartan. ${ }^{* \star} \mathrm{P}<0.01$ vs. control; ${ }^{\#} \mathrm{P}<0.01$ vs. Ang II group.

tent in the lysate was analyzed by the Bradford assay. Equal amounts of protein were resolved by electrophoresis in a $12 \%$ sodium dodecyl sulfate polyacrylamide gel (12\% running gel, $5 \%$ stacking gel) and transferred onto nitrocellulose membranes with a $0.2-\mathrm{mm}$-pore size. The membrane was incubated in blocking buffer [Tris-buffered saline (TBS), containing $0.1 \%$ Tween 20 and $5 \%$ non-fat milk] for $1 \mathrm{~h}$ at room temperature followed by the addition of the primary antibody monoclonal anti VEGF (1:1,000 in 5\% nonfat dry milk in TBS-T) for $2 \mathrm{~h}$ at room temperature. Then, the membrane was rinsed three times with TBS/Tween 20 and incubated with goat-anti-mouse IgG-peroxidase conjugate $(1: 2,000$ in $5 \%$ nonfat dry milk in TBS-T). Immunocomplexes were visualized using renaissance chemiluminescence reagents (Santa Cruz, CA, USA) and exposure to radiograph film (Kodak, Rochester, NY, USA). The optical density of immunoblots was determined by scanning densitometry and the result was presented in densitometric units. Translation was calculated by dividing the normalized VEGF density by the normalized $\beta$-actin density (VEGF/ $\beta$-actin ratio).

\section{Assessment of Cell Proliferation-MTT Assay}

The effect of Ang II or UII and a VEGF antagonist on cell proliferation was determined using the MTT assay. Briefly, adventitial fibroblasts were subcultured in 96-well plates and incubated with serum-free medium for $24 \mathrm{~h}$. Quiescent cultures were treated with UII $\left(10^{-8} \mathrm{~mol} / \mathrm{L}\right)$ or Ang II $\left(10^{-7} \mathrm{~mol} / \mathrm{L}\right)$ with or without the specific VEGF-neutralizing antibody for another $24 \mathrm{~h}$. IgG was used for negative control. Twenty microliters of MTT $(15 \mathrm{mg} / \mathrm{ml})$ was added to each well and incubated for $4 \mathrm{~h}$ at $37^{\circ} \mathrm{C}$. The culture supernatant was discarded by aspiration, and $150 \mu \mathrm{l}$ of DMSO was added to each well and incubated for $10 \mathrm{~min}$. Light absorbance was detected at $570 \mathrm{~nm}$ using an ELISA reader.

\section{Statistical Analysis}

The data were analyzed with the statistical software package SPSS 16.0 (SPSS, Chicago, IL, USA) and were displayed as the mean \pm standard deviation. Comparisons were done using the one-way ANOVA test, and post-hoc multiple comparisons were done with the least significant difference test. A P value of $<0.05$ was considered to be statistically significant.

\section{Results}

\section{Ang II Up-Regulates the Expression of VEGF in Adventitial Fibroblasts}

In the present investigation, we first explored whether adventitial fibroblasts were a novel source of VEGF and whether Ang II could stimulate VEGF secretion and synthesis in ad- 

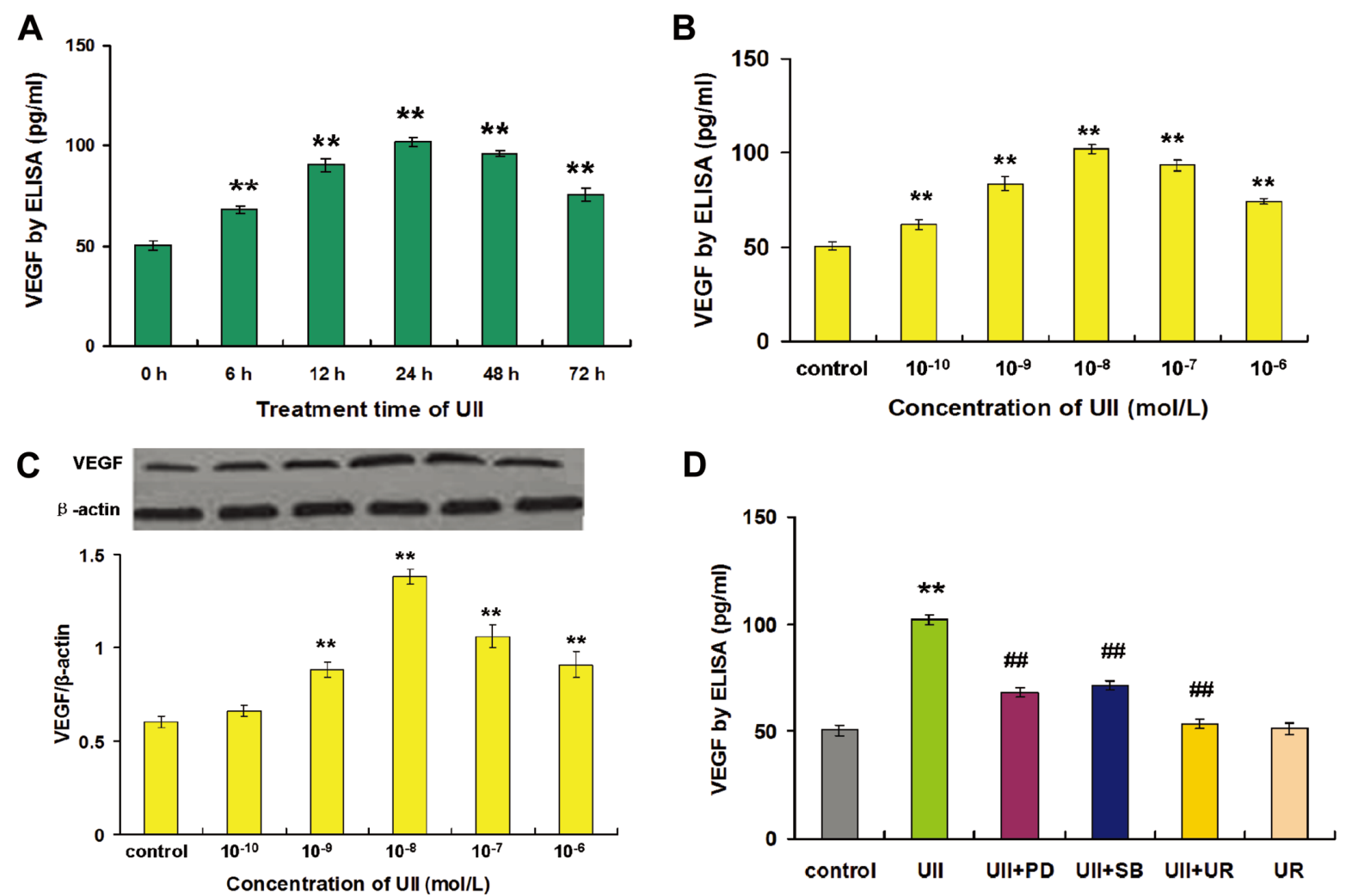

Figure 2. UII induces VEGF expression in adventitial fibroblasts. (A) Time course of Ull-mediated induction of VEGF secretion $(n=6)$. Rat adventitial fibroblasts were treated with UII $\left(10^{-8} \mathrm{~mol} / \mathrm{L}\right)$ for the time indicated. (B) Effect of different concentrations of UII on VEGF secretion in cultured adventitial fibroblasts in vitro $(n=6)$. Cells were stimulated with different concentrations of UII $\left(10^{-10}\right.$ to $\left.10^{-6} \mathrm{~mol} / \mathrm{L}\right)$ for $24 \mathrm{~h}$. (C) Effect of different concentrations of UII on VEGF expression in cultured adventitial fibroblasts in vitro assayed by western blot $(n=6)$. (D) Effect of different inhibitors on VEGF secretion in adventitial fibroblasts induced by UII $\left(10^{-8} \mathrm{~mol} / \mathrm{L}\right)(\mathrm{n}=6)$. PD, PD98059; SB, SB203580; UR, Urantide. ${ }^{* *} \mathrm{P}<0.01$ vs. control; \#\# $\mathrm{P}<0.01$ vs. Ull group.

ventitial fibroblasts. Adventitial fibroblasts were treated with different concentrations of Ang II $\left(10^{-10}\right.$ to $\left.10^{-6} \mathrm{~mol} / \mathrm{L}\right)$ for $24 \mathrm{~h}$ or with Ang II $\left(10^{-6} \mathrm{~mol} / \mathrm{L}\right)$ for 0 to $72 \mathrm{~h}$. We determined the baseline level of VEGF secretion and demonstrated that Ang II could induce VEGF secretion in adventitial fibroblasts in a time- and dose-dependent manner. As shown in Figure 1A, when adventitial fibroblasts were treated with Ang II $\left(10^{-6} \mathrm{~mol} / \mathrm{L}\right)$, VEGF secretion kept increasing from $6 \mathrm{~h}$ to $72 \mathrm{~h}$, with a maximal effect at $24 \mathrm{~h}$, when it was approximately 1.95 -fold higher than in the control group $(121.27 \pm 3.49 \mathrm{pg} / \mathrm{ml}$ vs. $62.13 \pm 1.75 \mathrm{pg} / \mathrm{ml}, \mathrm{P}<0.01)$. VEGF secretion in adventitial fibroblasts was affected at all doses of Ang II used in our study, with the maximal effect reached at $10^{-6} \mathrm{~mol} / \mathrm{L}(\mathrm{P}<0.01$, Figure $1 \mathrm{~B})$. Also, we confirmed the same trend in VEGF synthesis using western blot analysis (Figure 1C). To evaluate the role of two specific Ang II receptors $\left(\mathrm{AT}_{1} \mathrm{R}\right.$ and $\left.\mathrm{AT}_{2} \mathrm{R}\right)$ in Ang II-mediated induction of VEGF expression, adventitial fibroblasts were pre-treated with antagonists of these receptors, losartan and PD123319. Our results showed that the $\mathrm{AT}_{1} \mathrm{R}$ antagonist losartan caused a significant decrease in Ang II-induced VEGF secretion, whereas the $\mathrm{AT}_{2} \mathrm{R}$ antagonist PD123319 had no effect (Figure 1D), suggesting that Ang II-induced up-regulation of VEGF is mediated by the $\mathrm{AT}_{1} \mathrm{R}$ receptor. When adventitial fibroblasts were pre-treated with MAPK inhibitors (PD98059 and SB203580), we found that VEGF secretion was inhibited, suggesting that the MAPK pathway is also involved in the induction of VEGF expression by Ang II.

\section{UII Increases the Expression of VEGF in Adventitial Fibroblasts}

After confirming that Ang II induces VEGF secretion in adventitial fibroblasts, we studied the effect of UII on VEGF secretion. Adventitial fibroblasts were treated with different concentrations of UII $\left(10^{-10}\right.$ to $\left.10^{-6} \mathrm{~mol} / \mathrm{L}\right)$ for $24 \mathrm{~h}$ or with UII $\left(10^{-8} \mathrm{~mol} / \mathrm{L}\right)$ for different amounts of time. As with Ang II, a time-dependent and dose-dependent induction of VEGF expression was observed. Our results showed that, after $6 \mathrm{~h}$ of treatment, $10^{-8} \mathrm{~mol} / \mathrm{L}$ of UII induced VEGF secretion above baseline levels, and the induction peaked at 24h (102.02 \pm $2.28 \mathrm{pg} / \mathrm{ml}$ vs. $50.47 \pm 2.24 \mathrm{pg} / \mathrm{ml}, \mathrm{P}<0.01$, Figure $2 \mathrm{~A}$ ). Additionally, we discovered that the maximal effect was reached at $10^{-8} \mathrm{~mol} / \mathrm{L}$ of UII, and induction of VEGF secretion was less effective at other concentrations (Figure 2B). Also, we confirmed the same trend in VEGF synthesis through western blot analysis (Figure 2C). Nevertheless, pre-treatment with urantide or MAPK inhibitors (PD98059 and SB203580) could completely or partly inhibit UII-induced VEGF secretion in adventitial fibroblasts (Figure 2D), suggesting that the binding of UII to GPR14 and MAPK pathway receptors may play an important role in the induction of VEGF secretion by UII. 


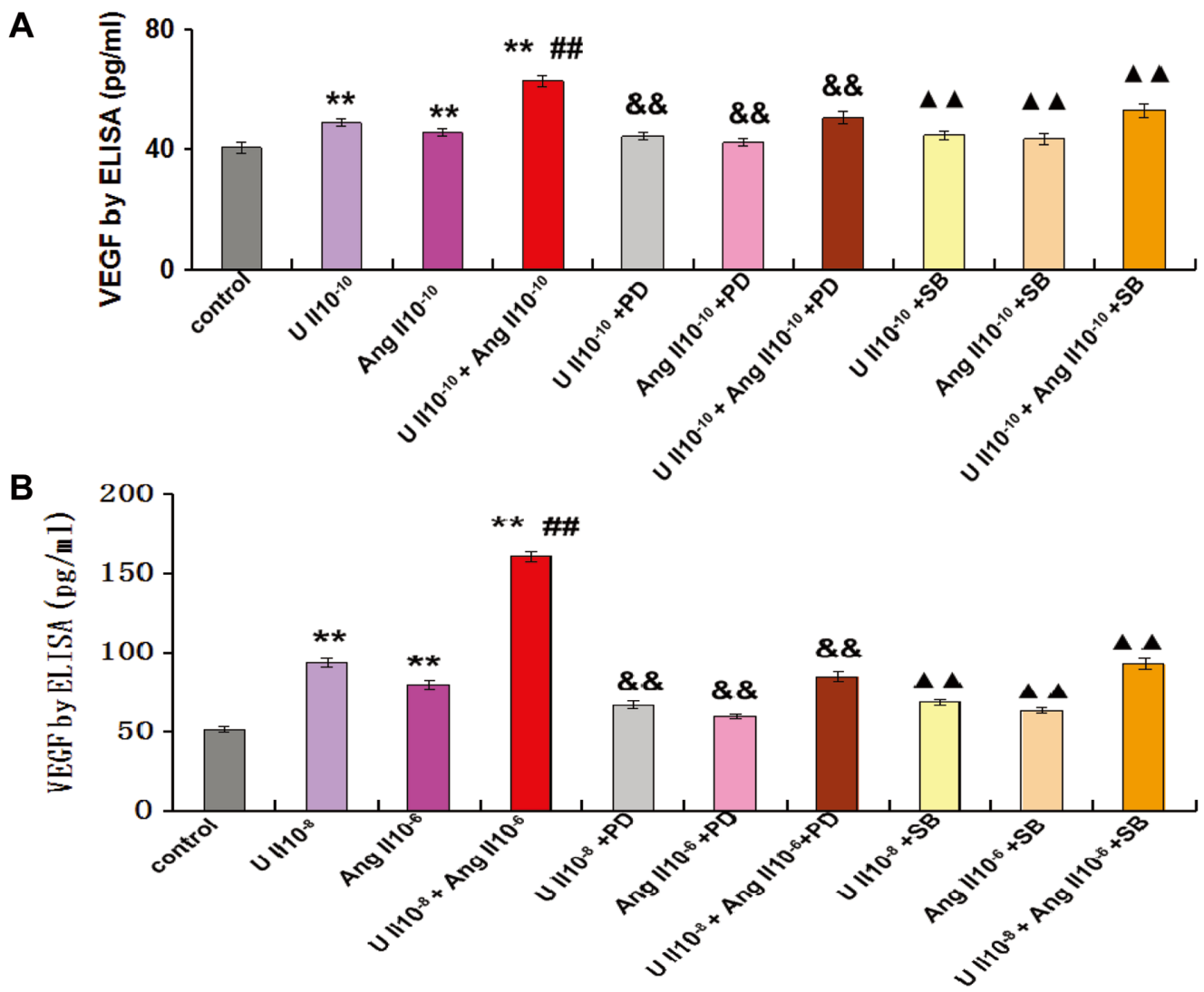

Figure 3. Synergistic effect of Ang II and UII on the secretion of VEGF in adventitial fibroblasts. (A) Synergistic effect of low concentrations of Ang II and UII (10-10 mol/L, respectively) ( $n=6)$. (B) Synergistic effect of maximal effect concentrations of Ang II and UII $\left(10^{-6} \mathrm{~mol} / \mathrm{L}\right.$ and $10^{-8} \mathrm{~mol} / \mathrm{L}$, respectively) $(\mathrm{n}=6)$. PD, PD98059; SB, SB203580. ${ }^{* *} \mathrm{P}<0.01 \mathrm{vs}$. control; \#\# $<0.01$ vs. Ull $10^{-10}$ group and Ang II $10^{-10}$ group; ${ }^{\& \&}, \wedge P<0.01$ vs. corresponding controls.

\section{UII and Ang II Have Synergistic Effects on VEGF Secretion in Adventitial Fibroblasts}

We found that low doses of Ang II or UII $\left(10^{-10} \mathrm{~mol} / \mathrm{L}\right)$ slightly induced VEGF secretion in adventitial fibroblasts when used separately. However, when adventitial fibroblasts were incubated with both together, VEGF secretion was up-regulated significantly (Figure 3A). Although $10^{-6} \mathrm{~mol} / \mathrm{L}$ of Ang II and $10^{-8} \mathrm{~mol} / \mathrm{L}$ of UII were found to exert maximal effects on VEGF secretion, they still had synergistic effects when used together (Figure 3B). Furthermore, our results demonstrated that inhibitors of the MAPK pathway inhibited the synergetic effects described above (Figures 3A,3B).

\section{Involvement of VEGF in UII- or Ang II-Induced Proliferation and Collagen Synthesis in Adventitial Fibroblasts}

We used a specific neutralizing antibody against VEGF (AbVEGF) to explore whether VEGF was involved in the proliferation and collagen synthesis in adventitial fibroblasts induced by UII or Ang II. Adventitial fibroblasts were pretreated with Ab-VEGF for $0.5 \mathrm{~h}$ and then incubated with UII $\left(10^{-8} \mathrm{~mol} / \mathrm{L}\right)$ or Ang II $\left(10^{-6} \mathrm{~mol} / \mathrm{L}\right)$. The results of the MTT and ELISA assays showed that Ab-VEGF significantly inhibited UII- or Ang II-induced proliferation and collagen I synthesis, suggesting that VEGF plays an important role in the above processes (Figures $4 \mathrm{~A}-\mathrm{D}$ ). We also observed that the neutralizing antibody against VEGF had an inhibitive effect on the basal proliferation of adventitial fibroblasts and collagen synthesis in these cells.

\section{Discussion}

Recent studies have shown that adventitia is the initiating site for vascular remodeling. There are few studies about the effect of UII and Ang II on VEGF expression in adventitial fibroblasts that play an important role in vascular remodeling. Although it was shown that VEGF could induce and was important for vascular remodeling in vivo, the role of VEGF in vascular remodeling induced by UII and Ang II was still unclear, which was characterized by the proliferation and collagen synthesis of adventitial fibroblasts. As vascular remodeling was a complex course in vivo, to clarify the role of VEGF in vascular remodeling induced by UII and Ang II more clearly, we performed an in vitro experiment in order to provide evidence for the above.

In the present study, we provide evidence for the first time that UII and Ang II can induce VEGF expression in adventitial fibroblasts and that VEGF is involved in UII- and Ang II-induced cell proliferation and collagen synthesis.

Previously, little was known regarding VEGF expression in adventitial fibroblasts. We demonstrate for the first time that VEGF is secreted at a baseline level in adventitial fibroblasts and show that UII and Ang II stimulate VEGF secretion in 
A

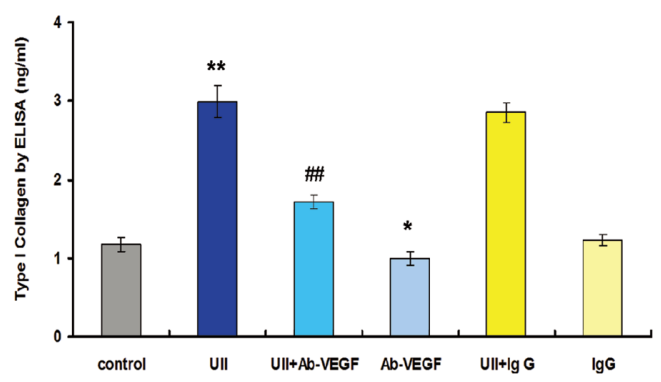

C

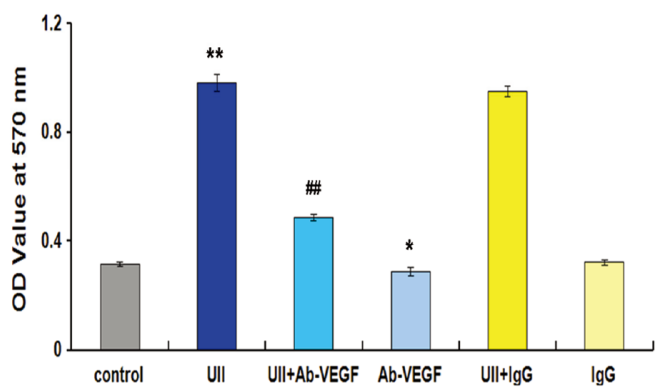

B

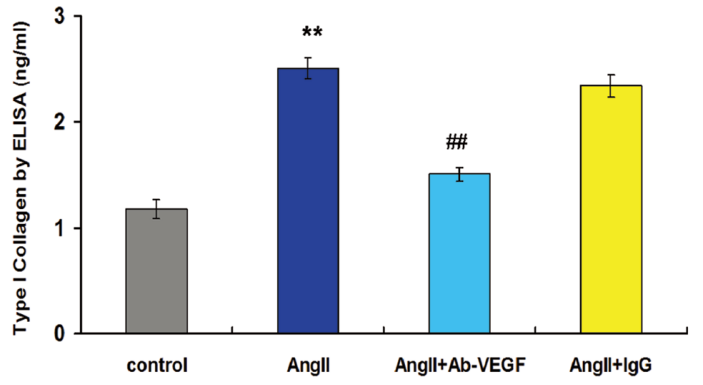

D

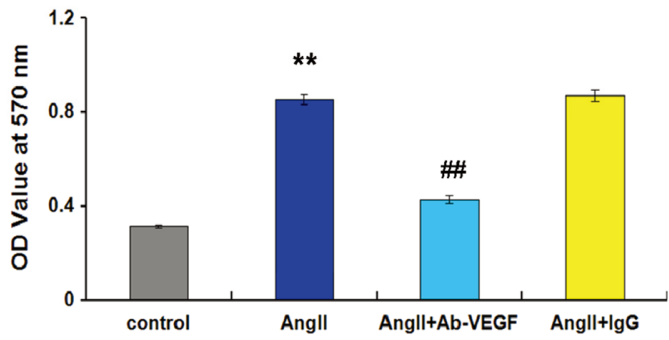

Figure 4. Involvement of VEGF in Ull-induced and Ang II-induced proliferation and collagen synthesis in adventitial fibroblasts. The results of ELISA $(\mathbf{A}, \mathbf{B})$ and $\mathrm{MTT}(\mathbf{C}, \mathbf{D})$ assays show a significant inhibition of Ab-VEGF on adventitial proliferation and collagen synthesis induced by Ang $\|\left(10^{-7} \mathrm{~mol} / \mathrm{L}\right)$ and UII $\left(10^{-8} \mathrm{~mol} / \mathrm{L}\right)$. All $\mathrm{n}=6$. ${ }^{*} \mathrm{P}<0.05 \mathrm{vs}$. control; ${ }^{* *} \mathrm{P}<0.01 \mathrm{vs}$. control; ${ }^{\# \#} \mathrm{P}<0.01 \mathrm{vs}$. UII group or Ang II group.

adventitial fibroblasts. Our results are similar to what has been observed in human endothelial cells, vascular endothelial cells and smooth muscle cells, where Ang II has been shown to induce VEGF expression. ${ }^{10,21}$ The time- and concentration-dependent properties observed in our study are consistent with a study done by Jin et al, which demonstrated that Ang II upregulates Flt, a receptor for VEGF, in a time- and dose-dependent manner. ${ }^{17}$ The only difference is that, in our study, the maximal effect of Ang II was seen at a concentration of $10^{-6} \mathrm{~mol} / \mathrm{L}$, while in theirs, it was seen at a concentration of $10^{-7} \mathrm{~mol} / \mathrm{L}$. This difference can be explained by receptor desensitization of Flt and the fixed half-life of VEGF. In contrast to Albertin et al, who did not observe the induction of VEGF expression by UII in human endothelial cells, we discovered that UII induces VEGF secretion in adventitial fibroblasts. ${ }^{19}$ The different cell types used may be a major cause for these conflicting results.

The mechanisms underlying the regulation of VEGF expression have been the subject of intensive investigation. Using a pharmacological approach, we demonstrated that stimulation of VEGF through UII in adventitial fibroblasts was mediated by the receptor GPR14 and pathways downstream of GPR14, including ERK and p38 signaling. These pathways were also shown to be involved in Ang II-induced VEGF expression in adventitial fibroblasts. It should be mentioned that it is $\mathrm{AT}_{1} \mathrm{R}$ and not $\mathrm{AT}_{2} \mathrm{R}$ that is involved in Ang II-mediated induction of VEGF expression, which is similar to observations in endothelial cells and cardiac myofibroblasts. ${ }^{21,22}$ Previous studies have suggested that there are different pathways responsible for the regulation of VEGF expression, depending on cell types and stimuli. Many studies have demonstrated that the MAPK pathway (especially ERK and p38) plays an important role in the regulation of VEGF expression. ${ }^{23-26}$ However, $\mathrm{Wu}$ et al reported that inhibition of ERK had no effect on VEGF expression in retinal microvascular endothelial cells. ${ }^{27}$ The reason for these contradictory results may be the differences in cell types and stimuli used in the studies. Our results demonstrate for the first time that the ERK and p38 pathways play an important role in the induction of VEGF expression through Ang II and UII in adventitial fibroblasts.

Many peptides interact with each other, and this appears to be the case based on our result that Ang II induces VEGF secretion in synergy with UII. Our results are similar to those of Wang and Lamarre, who showed that UII and Ang II have a synergistic effect on vasoconstriction in the endotheliumdenuded aorta and aortic rings with intact adventitia and endothelium. ${ }^{28,29}$ We further demonstrated that the ERK and p38 pathways were involved in the synergistic action of UII and Ang II. However, inhibitors of ERK and p38 could not fully block the synergistic action, suggesting that other pathways are also involved in the synergistic effects described above. Many studies have shown that PKC pathways are involved in the regulation of VEGF. Thus, it is possible that the PKC pathway, which plays an important role in the synergistic effect of UII and Ang II on vasoconstriction, might also be involved in the synergistic effect observed in our study. Additionally, it is possible that pathways such as JNK, STAT/ Smad and PKA, which can all regulate VEGF expression, might also be at work.

In this study, we demonstrate that VEGF-neutralizing antibodies can significantly inhibit Ang II- and UII-induced proliferation and collagen synthesis in adventitial fibroblasts. This 
suggests that VEGF may be a down-stream angiogenic mediator of Ang II and UII. However, VEGF-neutralizing antibodies could not completely inhibit the cell proliferation and collagen synthesis induced by UII and Ang II, suggesting that other factors that regulate cell proliferation and collagen synthesis, such as TGF- $\beta$ and PDGF, might also be involved. The induction of VEGF expression by Ang II and UII may be of considerable clinical significance, especially in diseases with defective vascular remodeling such as hypertension, atherosclerosis and restenosis. Pro-inflammatory cytokines play a crucial role in vascular remodeling in atherosclerosis and hypertension. VEGF produced by adventitial fibroblasts in response to UII and Ang II can activate neutrophils and monocytes, resulting in their adherence to endothelial cells. This might trigger pathophysiological changes in vascular remodeling. In addition, VEGF can induce the proliferation vascular endothelial cells and smooth muscle cells and the proliferation and migration of and collagen synthesis in adventitial fibroblasts, thus inducing vascular remodeling. The finding that the VEGFneutralizing antibody inhibits Ang II- and UII-induced proliferation and collagen synthesis provides new support for the use of drugs against VEGF in the treatment of cardiovascular diseases with vascular remodeling. However, it should be noted that the VEGF-neutralizing antibody also inhibited the baseline proliferation and collagen synthesis in adventitial fibroblasts. Therefore, application of a VEGF-neutralizing antibody in clinical practice should be applied with great caution.

In conclusion, UII and Ang II can synergistically stimulate VEGF secretion in adventitial fibroblasts. Several pathways, such as ERK and p38, are involved in the induction of adventitial fibroblast-mediated VEGF secretion by UII and/or Ang II. VEGF is involved in UII- and Ang II-mediated induction of adventitial fibroblast proliferation and collagen synthesis. Thus, our results clarify new mechanisms involved in vascular remodeling in the adventitia induced by UII and Ang II, and provide new evidence supporting the application of VEGFneutralizing antibodies in clinical practice.

\section{Acknowledgments}

This project was supported by the National Natural Science Foundation of China (No. 30871066). The experiments and article were completed and polished with the assistance of Professor Chaoshu Tang from the Department of Physiology and Pathophysiology of Peking University.

\section{References}

1. Sartore S, Chiavegato A, Faffin E, Franch R, Puato M, Ausoni S, et al. Contribution of adventitial fibroblasts to neointima formation and vascular remodeling: From innocent bystander to active participant. Cir Res 2011; 89: 1111-1121.

2. Stenmark KR, Davie N, Fird M, Gerasimovskaya E, Das M. Role of the adventitia in pulmonary vascular remodeling. Physiology (Bethesda) 2006; 21: 134-145.

3. Zhang YG, Li J, Li YG, Wei RH. Urotensin II induces phenotypic differentiation, migration and collagen synthesis of adventitial fibroblasts from rat aorta. Journal of Hypertension 2008; 26: 1119-1126.

4. Kinoshita T, Asia T. Role of rennin-angiotensin system inhibitors in patients undergoing off-pump coronary artery bypass grafting. Circ $J$ 2010; 74: 1852-1858.

5. Rakowski E, Hassan GS, Dhanak D, Ohlstein EH, Douglas SA, Giaid A. A role for urotensin II in restenosis following balloon angioplasty. J Mol Cell Cardiol 2005; 39: 789-791.

6. Hassan GS, Douglas, SA, Ohlstein EH, Giaid A. Expression of urotensin-II in human coronary atherosclerosis. Peptides 2005; 26: 2464 2472.

7. Barker TA, Massett MP, Korshunoc VA, Mohan AM, Kennedy AJ, Berk BC. Angiotensin II type 2 receptor expression after vascular injury: Differing effects of angiotensin-converting enzyme inhibition and angiotensin receptor blocker. Hypertension 2006; 48: 942-949.

8. Albertin G, Guidolin D, Sorato E, Spinazzi R, Mascarin A, Oselladore $\mathrm{B}$, et al. Pro-angiogenic activity of urotensin-II on different human vascular endothelial cell populations. Regul Pept 2009; 157: 64-71.

9. Iglewski M, Grant SR. Urotensin II-induced signaling involved in proliferation vascular smooth muscle cells. Vasc Health Risk Manag 2010; 6: 723-734.

10. Pan $\mathrm{P}, \mathrm{Fu} \mathrm{H}$, Zhang L, Huang H, Luo F, Wu W, et al. Angiotensin II upregulates the expression of placental growth factor in human vascular endothelial cells and smooth muscle cells. BMC Cell Biol 2010; 26: 36 .

11. Tsuruda T, Kato J, Hatakeyama K, Masuyama H, Cao YN, Imamura $\mathrm{T}$, et al. Antifibrotic effect of adrenomedullin on coronary adventitia in angiotensin II-induced hypertensive rats. Cardiovasc Res 2005; 65: $921-929$.

12. Matsui K, Yoshioka T, Murakami Y, Takahashi M, Shimada K, Ikeda U. Serum concentrations of vascular endothelial growth factor and monocyte-colony stimulating factor in peripheral arterial disease. Circ J 2003; 67: 660-662.

13. Sakamoto H, Sakamaki T, Kanda T, Tsuchiya Y, Sato M, Sato H, et al. Vascular endothelial growth factor is an autocrine growth factor for cardiac myxoma cells. Circ J 2004; 68: 488-493.

14. Eisenreich A, Boltzen U, Malz R, Schultheiss HP, Rauch U. Overexpression of alternatively spliced tissue factor induces the pro-angiogenic properties of murine cardiomyocytic HL-1 cells. Circ J 2011; 75: 1235-1242.

15. Yamamizu K, Yamashita JK. Roles of cyclic adenosine monophosphate signaling in endothelial cell differentiation and arterial-venous specification during vascular development. Circ J 2011; 75: 253 260.

16. Shin S, Lee SH, Park S, Kang SM, Chung N, Shim WH, et al. Soluble fms-like tyrosine kinase-1 and the progression of carotid intimamedia thickness: 24-month follow-up study. Circ J 2010; 74: 2211 2215.

17. Jin X, Ge X, Zhu DL, Yan C, Chu YF, Chen WD, et al. Expression and function of vascular endothelial growth factor receptors (Flt-1 and Flk-1) in vascular adventitial fibroblasts. J Mol Cell Cardiol 2007; 43: $292-300$.

18. Chen S, Lee JS, Wang A, Izduierdo-Lahuerta A, Gandhi NK, Danesh FR, et al. Angiotensin II stimulates alpha3 collagen production in mouse podocytes via TGF-beta and VEGF signaling: Implications for diabetic glomerulopathy. Nephrol Dial Transplant 2005; 20: $1320-$ 1328.

19. Albertin G, Guidolin D, Sorato E, Spinazzi R, Mascarin A, Oselladore $\mathrm{B}$, et al. Pro-angiogenic activity of Urotensin-II on different human vascular endothelial cell populations. Regulatory Peptides 2009; 157: 64-71.

20. Tsuruda T, Kato J, Cao YN, Hatakeyama K, Masuyama H, Imamura $\mathrm{T}$. Adrenomedullin induces matrix metalloproteinase-2 activity in rat aortic adventitial fibroblasts. Biochem Biophys Res Commun 2004; 325: $80-84$.

21. Chua CC, Hamdy RC, Chua BH. Upregulation of vascular endothelial growth factor by angiotensin II in rat heart endothelial cells. Biochim Biophys Acta 1998; 1401: 187-194.

22. Chintalgattu V, Nair DM, Katwa LC. Cardiac myofibroblasts: A novel source of vascular endothelial growth factor (VEGF) and its receptors Flt-1 and KDR. J Mol Cell Cardiol 2003; 35: 277-286.

23. Botero TM, Son JS, Vodopyanov D, Hasegawa M, Shelburne CE. MAPK signaling is required for LPS-induced VEGF in pulp stem cells. J Dent Res 2010; 89: 2644-2649.

24. Markel TA, Crisostomo R, Wang M, Herring CM. Iron chelation acutely stimulates fetal human intestinal cell production of IL-6 and VEGF while decreasing HGF: The roles of p38, ERK, and JNK MAPK signaling. Am J Physiol Gastrointest Live Physiol 2007; 292: G958-G963.

25. Yang XM, Wang YS, Zhang J, Li Y, Xu JF, Zhu J, et al. Role of P13K/Akt and MEK/ERK in mediating Hypoxia-induced expression of HIF- $\alpha$ and VEGF in Laser-induced rat choroidal neovascularisation. Invest Ophthalmol Vis Sci 2009; 50: 1873-1879.

26. Bian ZM, Elner SG, Elner VM. Thrombin induces VEGF expression in human retinal pigment epithelia cells. Invest Ophthalmol Vis Sci 2007; 48: $2738-2746$.

27. Wu H, Xia X, Jiang C, Wu J, Zhang S, Zheng Z, et al. High glucose attenuates insulin-induced VEGF expression in bovine retinal microvascular endothelial cells. Eye 2010; 24: 145-151.

28. Wang YX, Ding YJ, Zhu YZ, Shi Y, Yao T, Zhu YC. Role of PKC in the novel synergistic action of urotensin II and angiotensin II and in urotensin II-induced vasoconstriction. Am J Physilo Heart Circ Physiol 2007; 292: H348-H359.

29. Lamarre NS, Tallarida RJ. A quantitative study to assess synergistic interactions between urotensin II and angiotensin II. Eur J Pharmacol 2008; 586: 350-351. 